INTERnational JOURNAL OF MULtidisciplinaRy Research AND ANALysis

ISSN(print): 2643-9840, ISSN(online): 2643-9875

Volume 04 Issue 06 June 2021

DOI: 10.47191/ijmra/v4-i6-09, Impact Factor: 6.072

Page No.- 742-743

\title{
Didactic Conditions for the Formation of Discussion Competence among Students
}

\author{
Khusanova Mokhira Sherali qizi ${ }^{1}$, Bakhriddinova Madina Shavkatovna ${ }^{2}$ \\ ${ }^{1} 1$ st year master's student of SamSIFL. \\ ${ }^{2}$ Teacher of SamSIFL.
}

ANNOTATION: The article substantiates the need for the formation of discussion competence among students of linguistic universities. For this purpose, it is proposed to use an integrated approach. The methodology for developing an integrated approach is based on general scientific principles that take into account the specifics of the formation of students' discussion competence. Clarified the content of the concepts: "discussion competence" and "discussion speech". The didactic conditions for the formation of discussion competence are revealed, which provide a combination of factors of purposeful pedagogical influence on a student in order to form a discussion competence.

KEYWORDS: didactic, competence, communicative, discourse, strategic, integrity, universality, personal orientation, implementation, interlocutors.

The purpose of didactic support is the creation of a purposeful, comprehensively saturated with various didactic materials, information and educational environment for the effective flow of the process of forming students 'discussion competence. Communicative competence is a term in linguistics, not only refers to a language user's grammatical knowledge but also social knowledge about how and when to use utterances appropriately. The ability to use the language accurately and appropriately according to the communicative competence is to accomplish communication goals. The desired outcome of the use of the language is the ability to communicate competently, not the ability to use it exactly as a native speaker does. It means that the communicators of the language would communicate naturally without the strict tie of native speaker's influence. This condition really mirrors the existence of communicative competence as the achieved target of learning language.

It has become widely accepted that communicative competence should be the goal of language education central to good classroom practice. This is in contrast to previous views in which grammatical competence was commonly given top priority. The understanding of communicative competence has been influenced by the field of pragmatics and the philosophy of language concerning speech act.

The teachers of language, of course, lead their students based on what is suggested by the communicative competence that involve some areas: linguistics competence, Sociolinguistics competence, Discourse competence, and Strategic competence.

Linguistic competence is knowing how to use the grammar, syntax, and vocabulary of a language. Linguistic competence asks: What words do I use? How do I put them into phrases and sentences?

Sociolinguistic competence is knowing how to use and respond to language appropriately, given the setting, the topic, and the relationships among the people communicating. Sociolinguistic competence asks: Which words and phrases fit this setting and this topic? How can I express a specific attitude (courtesy, authority, friendliness, respect) when I need to? How do I know what attitude another person is expressing?

Discourse competence is knowing how to interpret the larger context and how to construct longer stretches of language so that the parts make up a coherent whole. Discourse competence asks: How are words, phrases and sentences put together to create conversations, speeches, email messages, newspaper articles?

Strategic competence is knowing how to recognize and repair communication breakdowns, how to work around gaps in one's knowledge of the language, and how to learn more about the language and in the context. Strategic competence asks: How do I know when I've misunderstood or when someone has misunderstood me? What do I say then? How can I express my ideas if I don't know the name of something or the right verb form to use?. 


\section{Didactic Conditions for the Formation of Discussion Competence among Students}

As a frequently suggested matter, the goal of teaching speaking should be related to the communicative competence. Developing communicative competence in teaching speaking is viewed very necessary because it will be highly valued in the process of communication. In developing the communicative competence, the primary point will be focused on the meaning and the understanding of information. Mitchell R. strengthens, the ultimate aim in language learning is to acquire communicative competence in talking and corresponding and psychological activity underlying the ability to say, listen to, write and read. In this case, the students feel free to communicate their ideas naturally in their speaking without hardly burdened with the grammar aspect.[3,1] Real life communication and social- culture interaction will highlight the existence of communicative competence in teaching speaking. Kosalapova claims that in natural communication, developing communicative competence must be practiced that the senders should develop their communicative competence by focusing on the use, not the usage. High motivation and prepared communicative tasks to the students are importantly considered in developing communicative competence in teaching speaking. They will be brought into situations of speaking atmosphere that really enable them to speak naturally. Interactional dialogue or face to face interaction, spontaneous improvised drama, and other communicative applied strategy and techniques become important parts for them in developing communicative competence. $[2,161]$

Debate is one of the methods that is a clearly structured and specially organized public exchange of thoughts between two parties on relevant topics. This is a kind of public discussion of the participants in the debate, aiming at persuading a third party, and not each other, that they are right. Therefore, the verbal and non-verbal means that are used by the participants in the debate are aimed at obtaining a certain result - to form a positive impression of their own position among the listeners.

Due to its characteristics - integrity, universality, personal orientation and orientation towards self-education of students - debates, today, are one of the most effective pedagogical technologies that allow not only mastering the skills corresponding to the studied discipline, but also contributing to the development of the creative activity of the individual, forming the ability to represent and defend their position, public speaking skills, the ability to conduct a tolerant dialogue and leadership qualities.

Absolutely, all can improve their speaking ability through the implementation of communicative competence in teaching speaking on them. Communicative competence as the aspect of our competence enables the students to convey meaning and interpret messages and to negotiate meanings interpersonally within specific context. When the students' speaking of English is natural, their communicative competence for that their performance is already developed. Developing communicative competence in teaching speaking is faster and better if they are exposed to maximum natural communication. Consequently, the speaking teachers must speak, teach, and communicate English naturally and fluently. As informed at previous statement, during natural communication process, the meaning or understanding is primary. It means that the use is priority to develop the students' comprehension on messages or information communicated by their interlocutors. The use is natural verbal that must be understood by the teacher in guiding the students in teaching speaking. Absolutely, understanding this way will be helpful to develop the students' acquisition. The acquisition meant here is the students' mastery of the language. More interesting, challenging materials, and prepared oral communicative tasks offer the success of developing communicative competence in teaching speaking. In teaching speaking communicatively, conversation should constantly interpret what is being said as the conversation continues that interacting with the interlocutor will focus on the analysis of the context being conversed. In this case, the students in speaking, of course, use the language in context, in real- life situation, and it is one of the jobs considered by the speaking teacher in applying materials and oral communicative task in developing communicative competence.

The success of developing communicative competence in teaching speaking is inseparable with the materials or tasks given to the students. The speaking teachers should really pay attention to tasks given that are more focused on oral communicative ones. The tendency of relying on student- centered communicative task is strongly expected to achieve the target of communicative competence development. Absolutely, the oral communicative tasks will activate the students' interest to communicate their ideas in oral form naturally. They will enjoy their communication process created without much interference of teacher.

\section{REFERENCES}

1) Двуличанская Н. Н. Интерактивные методы обучения как средство формирования ключевых компетенций // Наука и образование: электронное научно-техническое издание, 2011

2) Косолапова М.А., Ефанов В.И. Развитие профессиональной компетентности преподавателя вуза при повышении квалификации // Материалы международной научно-методической конференции «Современное образование: проблемы обеспечения качества подготовки специалистов в условиях перехода к многоуровневой системе высшего образования» Томск: ТУСУР, 2012, с. 161-162.

3) Mitchell, R. Communicative Interaction Research Project: Final Report. Department of Education, University of Stirling. Mitchell, R., Parkinson, B. and Johnstone, R., 1985 